$\begin{gathered}\text { Ana Dili Eğitimi Dergisi } \\ \text { Journal of Mother Tongue Education } \\ \text { www.anadiliegitimi.com }\end{gathered}$
Geliş/Received: 18.04 .2018 Kabul/Accepted:03.12.2018

\title{
Öğretmen Adaylarının Türkçe Öğretimi Uygulamalarına İlişkin Görüşleri*
}

\author{
Aliye ERDEM ${ }^{* *}$ \\ Ayşegül BAYRAKTAR ${ }^{* * *}$
}

Öz

Sınıf öğretmenliği anabilim dalında öğrenim gören öğretmen adaylarının Türkçe öğretimi uygulamalarına ilişkin görüşlerinin incelendiği bu araştırmada veriler 26 sınıf öğretmeni adayının Türkçe öğretimine ilişkin görüşlerini belirlemeye yönelik açık uçlu soruların yer aldığı bilgi formu ile toplanmıştır. Araştırmada elde edilen veriler betimsel çözümleme tekniği kullanılarak çözümlenmiş ve yorumlanmıştır. Araştırma bulguları öğretmen adaylarının Türkçe derslerinde dikkat çekme ve güdüleme için en çok; açık uçlu sorular kullandıklarını, görsellerden yararlandıklarını, konuyla ilgili kısa videolar izlettiklerini ve çocuk edebiyatından metinler okuduklarını göstermiştir. Türkçe derslerinde en fazla; soru-cevap, anlatım, drama, 5E öğrenme döngüsü ve tartışma yöntem ve teknikleri kullanılmıştır. Kullanılan metinlerin seçiminde öğrencilerin ön bilgileri, gelişim özellikleri, metnin ilgi çekiciliği, yazım ve içerik olarak uygun olması gibi özellikler dikkate alınmıştır. Öğretmen adaylarııı Türkçe derslerinde; sınıf hâkimiyeti ve öğrenciyi derse katabilme, iletişim kurma ve öğrencilerin dikkatini çekme, soru-cevap yöntemini etkili kullanma ve etkinlikleri yönlendirme, vurgulu konuşma konularında kendilerini başarılı buldukları görülmüştür.

Anahtar Kelimeler: Türkçe öğretimi, öğretmen adayları, öğrenme-öğretme süreci.

\section{Pre-Service Teachers' Opinions regarding Practices of Turkish Language Arts Course}

\begin{abstract}
This study investigated pre-service teachers' opinions regarding practices in teaching Turkish Language arts course. The data was collected through 26 pre-service teachers' responses to the Opinion Form consisting of open-ended questions. The collected data were analysed and interpreted through descriptive analysis techniques. Findings revealed that in order to draw attention and motivate students, pre-service teachers mostly used open-ended questions, used visuals and short videos, and read children's literature books. When teaching the course, question and answer, lecture, drama, the 5E learning cycle and discussion were the most commonly used teaching methods. Students' prior knowledge and developmental characteristics, whether the texts were interesting and appropriate or not were considered when determining which texts to be used. Pre-service teachers stated that they were successful at managing the classroom, allowing students to participate in the lesson, conducting an effective communication, taking students' attentions, using question and answer technique, organizing activities, and using intonations when speaking.
\end{abstract}

Keywords: Turkish language teaching, pre-service teachers, learning-teaching process.

\footnotetext{
* Bu çalışmanın bir bölümü, Muğla Sıtkı Koçman Üniversitesi tarafından 31 Mayıs-3 Haziran 2016 tarihlerinde gerçekleştirilen 3. Uluslararası Avrasya Eğitim Araştırmaları Kongresi'nde (EJER) sözlü bildiri olarak sunulmuştur. ** Dr. Öğr. Üyesi, Ankara Üniversitesi, Eğitim Bilimleri Fakültesi, Temel Eğitim Bölümü, Ankara, aliye.erdem@ankara.edu.tr, ORCID: 0000-0001-6602-7239

*** Dr. Öğr. Üyesi, Ankara Üniversitesi, Eğitim Bilimleri Fakültesi, Temel Eğitim Bölümü, Ankara, abayraktar@ankara.edu.tr, ORCID: 0000-0002-1700-8899
} 


\section{Giriş}

Illkokul, büyük oranda bireylerin temel bilgi ve becerileri kazandığı, tutum ve değerlerin oluştuğu bir dönemi kapsar. Özellikle bu yıllarda verilen eğitim-öğretimin niteliği, bireyin hem eğitim yaşantısını hem de bireysel yaşantısını doğrudan etkilemektedir. Bu durum, ilkokulda eğitim-öğretim hizmetlerini yürüten sınıf öğretmeninin sorumluluğunu daha da arttırmaktadır. Çünkü teknolojik gelişmeler ne kadar hızlı olursa olsun özellikle ilköğretimde sınıf içerisinde öğretmenin yerini dolduracak teknolojik bir araç yoktur (Akyol, 2010).

Bireylerin bilgi birikimlerinin temelini oluşturmada ilkokuldaki sınıf öğretmenlerinin etkisinin incelendiği araştırmalar sınıf öğretmenlerin kişilerin geleceklerini belirlemedeki etkilerine vurgu yapmaktadır (Boyacı ve Kılıç, 2017). Senemoğlu (1992), sınıf öğretmeninin, bireyin bilişsel gelişiminde can alıcı öneme sahip dönemlerden 5-11 yaşlarındaki çocukları etkileyerek gelecek nesillerin bilişsel gelişimini besleyen; bireyin kendine, topluma ve kendi dışındaki dünyaya karşı tutumlarının çerçevesini çizen; gelecek nesillerin yaşama biçimini büyük ölçüde etkileyen iletişim, araştırma ve yaratıcılık becerilerinin gelişimini hızlandıran kişi olduğunu ifade eder. Eğitim ve öğretimi etkileyen en önemli öge olan öğretmen, öğrenme-öğretme sürecinde en çok öğrenciler ile iletişim kurar.

İlkokul öğrencileri, anadilini ailelerinden öğrenmiş olarak okula gelirler. Ancak, ailenin çocuğa verdiği temel anadili eğitimi oldukça önemli olmakla birlikte, dilin kuralları ve doğru kullanımı açısından yeterli olmayabilir. Güncel Türkçe Öğretim Programı kapsamında gerçekleştirilen etkinlikler aracılığıyla öğrencilerin dil becerilerini kazanmaları beklenir. Bu düşünceden hareketle öğretmenlerin, özellikle de sınıf öğretmenlerinin dil becerilerini kazandırma konusunda önemli sorumluluklarının olduğu düşünülmektedir. Dolayısıyla, sınıf öğretmenlerinin, öğrencilere nitelikli bir anadili eğitimi verebilmeleri için kendilerinin yeterli donanıma sahip olmaları gerekmektedir.

Anadili öğretiminin temel amacı, bireylerin düşünme ve iletişim becerilerini ve anlama gücünü geliştirmek, toplumsallaşma süreçlerine katkıda bulunmak, dinleme ve okuma alışkanlığı ve zevki kazandırmak, bireylerde sözcük dağarcığını zenginleştirmek, temel dilbilgisi kurallarını öğretmek ve dil bilinci ve sevgisini oluşturmaktır (Kavcar, 1988; Kavcar, Oğuzkan ve Sever, 2005). Ülkemizde anadili öğretimi tüm dersler aracılığıyla dolaylı olarak yapılmaya çalışılsa da anadili öğretiminin temel sorumluluğu Türkçe derslerindedir. Bu nedenle bireylere bilişsel gelişmelerine ve toplumsal gereksinimlerine dayalı olarak gerekli dilsel beceri ve alışkanlıkların kazandırılmasında Türkçe öğretimine önemli sorumluluklar düşmektedir (Kavcar, Oğuzkan ve Sever, 2005).

Türkçe öğretiminin temel amacı, anlama ve anlatma becerileri gelişmiş, duyarlı bireyler yetiştirmektir. Bu amaç doğrultusunda bireylerin dinleme, okuma, konuşma ve yazma becerilerini bilimsel bir anlayışla planlı bir biçimde geliştirmeye, onlara Türkçeyi doğru ve etkili kullanabilme 


\section{Öğretmen Adaylarının Türkçe Öğretimi Uygulamalarına İlişkin Görüşleri}

becerisi kazandırmaya çalışılmaktadır. Ayrıca Türkçe öğretimi içerisinde dil bilgisi kuralları sezdirilerek, dil becerilerinin gelişimine dayanak oluşturularak, içinde yaşanan dili kavratmak hedeflenmektedir (Adalı, 1983; Erdem ve Çelik, 2011). Bu amaçların yerine getirilmesi birinci sınıftan başlayıp sekizinci sınıfın sonuna kadar devam eden öğrenme sürecinde Türkçe öğretiminin etkili olması ile olanaklıdır (Sever, 2003).

İlkokulda etkili ve nitelikli bir Türkçe öğretiminin gerçekleştirilebilmesi sınıf öğretmenlerinin niteliğiyle doğrudan ilişkilidir. Öğretmen, öğrenme-öğretme süreçlerinde en etkin role sahip olan, öğrenciyle sürekli etkileşim hâlinde bulunan, eğitim programının uygulanmasından sorumlu olan, öğretimi yönlendiren, eğitim-öğretimle ilgili değerlendirme çalışmalarını yöneten kişidir (Evran Acar, 2010). Bu nedenle sınıf öğretmenlerinin Türkçe öğretimi ile ilgili temel bilgi, beceri, ilke ve yöntemleri içeren kazanımlara sahip olması beklenir. Sınıf öğretmenleri Türkçe öğretimiyle ilgili söz konusu bu kazanımları, lisans eğitimleri sırasında Türkçe öğretimi dersi kapsamında öğrenmektedirler. Bu düşünceden hareketle, öğretmen adaylarının Türkçe öğretimi dersi kapsamında gerçekleştirdikleri uygulamalara ilişkin görüşlerinin belirlenmesinin, öğretmen adaylarının Türkçe öğretimi konusundaki niteliklerini artırmaya katkı sağlayacağı düşünülmektedir.

Bu araştırmanın amacı, 2015-2016 eğitim-öğretim yılında Ankara Üniversitesi Eğitim Bilimleri Fakültesi İlköğretim Bölümü Sınıf Öğretmenliği Anabilim Dalı’nda öğrenim gören öğretmen adaylarının Türkçe öğretimi uygulamalarına ilişkin görüşlerini belirlemektir. Bu amaç doğrultusunda araştırmada şu sorulara yanıt aranmıştır:

1. Öğretmen adayları Türkçe derslerinde dikkat çekme ve güdüleme için neler yapmaktadırlar?

2. Öğretmen adayları Türkçe derslerinde hangi yöntem, teknikler ile materyalleri kullanmaktadırlar?

3. Öğretmen adayları Türkçe derslerinde incelemek üzere metin/şiir okumakta mıdır? Metin/şiir seçerken nelere dikkat etmektedirler?

4. Öğretmen adayları Türkçe derslerinde grup çalışmalarına yer vermekte midir? Neden?

5. Öğretmen adayları Türkçe derslerinde öğrencilere uygun geribildirimler vermekte midir? Neler söylemektedirler?

6. Öğretmen adaylarının Türkçe derslerinde sınıf yönetimine ilişkin görüşleri nelerdir?

7. Öğretmen adayları Türkçe derslerinde öğrencilerin etkin katılımını sağlamak için neler yapmaktadırlar?

8. Öğretmen adaylarının deneyimlerine bağlı olarak kendilerinde başarılı buldukları ve geliştirmeleri gereken yönleri nelerdir? 
Araştırma sorularının hazırlanma sürecinde ve sorular hazırlandıktan sonra uzman görüşleri alınmıştır. Araştırma sorularının çoğu açık uçludur. Bu tür soruların kullanılmasıyla incelenen konunun daha esnek ve keşfedici bir bakış açısıyla araştırılacağı ve çözümleneceği umulmaktadır.

\section{Yöntem}

\section{Araştırmanın Modeli}

$\mathrm{Bu}$ araştırma nitel araştırma yöntemlerinden durum çalışması modeline göre gerçekleştirilmiştir. Nitel araştırma gözlem, görüşme ve doküman analizi gibi nitel veri toplama yöntemlerinin kullanıldığı, algıların ve olayların doğal ortamda gerçekçi ve bütüncül bir biçimde ortaya konmasına yönelik nitel bir sürecin izlendiği araştırma olarak tanımlanabilir (Yıldırım ve Şimşek, 2016: 41). Durum çalışmalarında belli bir duruma ilişkin sonuçlar ortaya konmaya çalışılır. Bu araştırmada öğretmen adaylarının Türkçe dersi öğretimlerine yönelik görüş ve deneyimleri incelenmiştir. Durum çalışmalarında durumlar birbirinden farklı olduğu için genelleme yapmak söz konusu değildir (Yıldırım ve Şimşek, 2016). Ancak bu çalışmadan elde edilen sonuçlarla benzer durumlara yönelik örneklerin verilebilmesi amaçlanmıştır.

\section{Araştırma Grubu}

Bu araştırmanın çalışma grubu 2015-2016 eğitim öğretim yılı bahar yarıyılında, Ankara Üniversitesi Eğitim Bilimleri Fakültesi Sınıf Öğretmenliği Anabilim Dalı’nda kayıtlı olan, "Türkçe Öğretimi" dersini almış ve bu çalışmaya katılmaya gönüllü olan toplam 26 sınıf öğretmeni adayından oluşmaktadır. Bu durum çalışmasında öğretmen adaylarının Türkçe dersi öğretimine yönelik görüş ve deneyimlerinin keşfedilmesi ve açıklanmasında amaçlı örnekleme yönteminin uygun bir yöntem olduğu düşünülmektedir (Yıldırım ve Şimşek, 2016). Katılımcılara ulaşmanın daha çabuk ve maliyetinin düşük olması ile tanıdık bir grupla çalışmanın daha pratik olacağı düşünüldüğünden araştırmanın çalışma grubu amaçlı örnekleme yöntemlerinden kolay ulaşılabilir durum örneklemesi ile belirlenmiştir.

\section{Veri Toplama Aracı, Verilerin Toplanması ve Verilerin Çözümlenmesi}

Araştırma verileri, sınıf öğretmeni adaylarının Türkçe öğretimine ilişkin görüşlerini belirlemeye yönelik açık uçlu soruların yer aldığı bilgi formu ile toplanmıştır. Bilgi formunda yer alan sorular oluşturulurken öncelikle ilgili alanyazın incelenmiş, oluşturulan taslak görüşme formu alan uzmanlarının görüşlerine sunulmuş ve alınan dönütler doğrultusunda sorulan sorulardan yönlendirici olanlar, çok boyutlu olanlar ve cevabı evet-hayır şeklinde olan bazı kapalı uçlu sorular bilgi formundan çıkarılarak veri toplama aracına son hali verilmiştir. 
Nitel araştırmalarda veri çözümlemesi kapsamında veriler, birimlere ayrılır, kodlanır, veriler arasındaki bağlamları görmek ve temalar oluşturmak için sentezlenir (Bogdan ve Biklen, 2007). Bu araştırmada veriler, nitel araştırmada veri çözümleme tekniklerinden betimsel çözümleme tekniği kullanılarak çözümlenmiş ve yorumlanmıştır. Betimsel çözümlemede elde edilen veriler, daha önceden belirlenen temalara göre özetlenir ve yorumlanır (Yıldırım ve Şimşek, 2011).

Verilerin çözümlemesinde araştırma sorularıyla ilgili olarak toplanan verilerin detaylı olarak gerçek durumu yansıtmasına çalışımıştır. Bunun için de araştırmaya katılan öğretmen adaylarının görüş ve deneyimleri mümkün olduğunca doğrudan sunulmuştur (Yıldırım ve Şimşek, 2016). Betimsel çözümleme ile veriler çözümlenirken araştırmacıların görüş ve yorumlarına yer verilmemiştir. Bulguların sunumunda örnekler ve veriler ışığında yoruma gidilmiştir. Bu araştırmanın verileri araştırma sorularına göre belirlenen temalar altında sunulmuştur. Araştırma verilerinin çözümlenmesinde öncelikle araştırma sorularına bağlı olarak betimsel çözümleme için bir çerçeve oluşturulmuştur. Daha sonra betimsel çözümleme için oluşturulan çerçeveye örnek olan veriler bir araya getirilmiş, ilgili olanlar birleştirilmiş ve bulguların yazımında kullanılacak doğrudan alıntılar belirlenmiştir. Daha sonra tablolar halinde verilen bulgular betimlenmiş ve yorumlanmıştır. Araştırmaya katılan her bir öğretmen adayına 1'den 26'ya kadar numara verilmiştir (örn. K1). Öğretmen adaylarının yorumları ve cevapları K1, K3 vb. kodlanmış numaralarla belirtilmiştir (K1: araştırmaya katılan bir numaralı öğretmen adayını belirtmektedir).

\section{Bulgular}

$\mathrm{Bu}$ başıı altında, çalışma grubundaki öğretmen adaylarının araştırma sorularına dair verdikleri yanıtlar tablolar ile sunulmuş ve yorumlanmıştır.

“Öğretmen Adayları Türkçe Derslerinde Dikkat Çekme ve Güdüleme İçin Neler Yapmaktadırlar?” Sorusuna ilişskin Öğretmen Adaylarının Görüşlerinin Dağılımı

Araştırma kapsamında öğretmen adaylarına yöneltilen "Türkçe derslerinizde dikkat çekme ve güdüleme için neler yapmaktasınız?" sorusuna öğretmen adaylarının verdiği yanıtların dağılımı Tablo 1 'de en sık gözlenenden en az gözlenene doğru listelenmiştir:

\begin{tabular}{clc}
\multicolumn{2}{c}{ Tablo } & Öğretmen adaylarının dikkat çekme ve güdüleme için yaptığı etkinlikler \\
\hline No & Yapılan Etkinlikler & $\mathrm{f}$ \\
1 & Açık uçlu sorular sorma & 15 \\
2 & Görsellerden yararlanma & 9 \\
3 & Konuyla ilgili kısa videolar izletme & 7 \\
4 & Çocuk edebiyatından metinler okuma & 5 \\
5 & Günlük yaşamla ilgili sorular sorma & 2 \\
6 & Konuyla ilgili çocuk şarkıları dinletme & 2 \\
7 & Fıkra anlatma & 2 \\
8 & Drama yaptırma & 1 \\
\hline
\end{tabular}


Tablo 1'e göre Türkçe derslerinde dikkat çekme ve güdüleme için öğretmen adaylarının en çok açık uçlu sorular kullandıkları, görsellerden yararlandıkları, konuyla ilgili kısa videolar izlettikleri, çocuk edebiyatından metinler okudukları görülmektedir. Öğretmen adaylarının büyük çoğunluğunun dikkat çekme ve güdüleme için açık uçlu soruları kullanmaları, konuyla ilgili görseller ya da videolar bulmaya göre daha kolay bir etkinlik olduğu için çoğunlukla tercih edildiği düşünülebilir. Açık uçlu sorular konuyla ilgili ön bilgiler ve ön yaşantıların bilişsel olarak hatırlanmasını sağlarken konuyla ilgili görseller ve videolar görüntü ve ses olarak da hatırlamayı kolaylaştırdığı için daha etkileşimli bir ortam sağlayabilir. Etkileşimli bir ortamın sağlanmasında önemli bir role sahip olan dramanın dikkat çekme ve güdülemede çok az kullanılması ise dikkat çekici bir veri olarak değerlendirilebilir.

“Öğretmen Adayları Türkçe Derslerinde Hangi Yöntem, Teknikler ile Materyalleri Kullanmaktadırlar?” Sorusuna iliş̧kin Öğretmen Adaylarının Görüşlerinin Dağılımı

Araştırma kapsamında öğretmen adaylarına yöneltilen "Türkçe derslerinizde hangi yöntem, teknikler ile materyalleri kullanmaktasınız?” sorusuna öğretmen adaylarının verdiği yanıtların dağıııı Tablo 2 ve Tablo 3'te sunulmuştur:

Tablo 2. Öğretmen adaylarının kullandıkları yöntem ve teknikler

\begin{tabular}{clc}
\hline No & Kullanılan Yöntem ve Teknikler & $\mathrm{f}$ \\
1 & Soru-cevap & 20 \\
2 & Anlatım & 14 \\
3 & Drama & 5 \\
4 & 5E öğrenme döngüsü & 5 \\
5 & Tartışma & 4 \\
6 & Grup çalışması & 2 \\
7 & Beyin fırtınası & 2 \\
8 & İstasyon & 2 \\
9 & Gösteri & 1 \\
10 & Örnek olay & 1 \\
11 & Rol oynama & 1 \\
12 & Eğitsel oyunlar & 1 \\
\hline
\end{tabular}

Tablo 2 incelendiğinde öğretmen adaylarının Türkçe derslerinde en fazla; soru-cevap, anlatım, drama, 5E öğrenme döngüsü ve tartışma yöntem ve tekniklerini kullandıkları görülmektedir. Öğretmen adayları az sayıda da olsa grup çalışması, beyin fırtınası ve istasyon tekniklerini de uygulamaktadırlar. Bu tablodaki verilerden hareketle öğretmen adaylarının her ne kadar en çok sorucevap ve anlatım yöntem-tekniklerini tercih etseler de konunun uygunluğu doğrultusunda öğrencilerin öğrenme-öğretme sürecine aktif katılımlarını sağlayan yöntem ve teknikleri de uyguladıkları söylenebilir. 
Tablo 3. Öğretmen adaylarının kullandıkları materyaller

\begin{tabular}{clc}
\hline No & Kullanılan Materyaller & $\mathrm{f}$ \\
1 & Yansıtıcı & 16 \\
2 & Bilgisayar & 9 \\
3 & Tahta & 4 \\
4 & Ders Kitabı & 4 \\
5 & Türkçe sözlük & 4 \\
6 & Çalışma yaprakları & 4 \\
7 & Yazım Kılavuzu & 3 \\
8 & Renkli kartonlar & 2 \\
9 & Kartondan, kartlardan ya da kâğıtlardan & 1 \\
\hline
\end{tabular}

Tablo 3'e göre öğretmen adayları Türkçe derslerinde en fazla yansıtıcı, bilgisayar, tahta, ders kitabı, Türkçe sözlük ve çalışma yapraklarını kullanmaktadırlar. Öğretmen adaylarının büyük çoğunluğunun yansıtıcı kullanmaları, derste teknolojik araçlardan etkin bir biçimde yararlandıklarını göstermektedir.

“Öğretmen Adayları Türkçe Derslerinde Incelemek Üzere Hangi Tür Metinleri Kullanmaktadır? Metin/Şiir Seçerken Nelere Dikkat Etmektedirler?” Sorusuna ilişkin Öğretmen Adaylarının Görüşlerinin Dağılımı

Araştırma kapsamında öğretmen adaylarına yöneltilen "Türkçe derslerinizde incelemek üzere hangi tür metinleri kullanıyorsunuz? Metin seçerken nelere dikkat ediyorsunuz?" sorularına öğretmen adaylarının verdiği yanıtların dağılımı Tablo 4'te ve öğretmen adaylarının kendi ifadelerinden alıntılarda sunulmuştur:

Tablo 4. Öğretmen adaylarının kullandıkları metin türleri

\begin{tabular}{clc}
\hline No & Kullanılan Metin Türleri & $\mathrm{f}$ \\
1 & Çocuk edebiyatı/Öykü & 20 \\
2 & Ders Kitabındaki metinler & 3 \\
3 & Şiir & 3 \\
4 & Fıkra & 1 \\
\hline
\end{tabular}

Tablo 4'e göre öğretmen adayları Türkçe derslerinde en fazla çocuk edebiyatı ürünlerinden öyküleri, ders kitabındaki metinleri ve şiirleri kullanmaktadırlar. Öğretmen adaylarının Türkçe derslerinde metin seçerken nelere dikkat ettiklerine yönelik görüşlerinden bazıları şunlardır:

"Metin kullandım. Çocukların eleştirel düşünmelerini sağlamak amacıyla onların bir farkındalık kazanmalarını istedim." (K1) 
"Derste incelemek üzere "Peşin Hüküm" isimli metin kullanıldı. Metni seçerken öğrencilerin ön bilgileri, ilgi ve istekleri, gelişsim özelliklerin ve öğrenci düzeyi dikkate alınarak seçildi." (K2)

"Derste öğrencilere bir metin işledim. Bu metni seçerken de metnin içeriğinin çocukların düzeyine uygun olup olmadığına, metinde bir konu bütünlüğünün var olup olmadığına, yazım yanlışlarına, metnin uzunluğuna, dilbilgisine ve öğrencilere verilen mesajın yanlış olmamasına özen gösterdim." (K3)

"Incelemek için "Canım isterse?" adlı metin kullanılmıştır. Metin seçilirken öncelikle çocukta merak uyandırarak ilgi çekmesine, verdiği mesajın çocuğa göre olmasına, metinin gerek dil bakımından gerekse anlaşılması yönünden çocuğu zorlamayacak bir metin olmasına dikkat edildi." (K16)

Öğretmen adayları Türkçe derslerinde metin seçerken en çok; öğrencilerin ön bilgileri, gelişim özellikleri, öğrencilerin bilişsel düzeyi, metinlerin ilgi çekiciliği, metnin dil ve anlatım yönünden yazım ve içerik olarak çocuğun düzeyine uygun olması gibi özellikleri dikkate aldıklarını belirtmişlerdir. Belirtilen görüşler doğrultusunda, öğretmen adaylarının metin seçerken pek çok değişkeni dikkate aldıkları ve bu konuda duyarlı davrandıkları söylenebilir.

"Öğretmen Adayları Türkçe Derslerinde Küme Çalışmalarına Yer Vermekte Midir? Neden?" Sorusuna ilişskin Öğretmen Adaylarının Görüşlerinin Dağılımı

Araştırma kapsamında öğretmen adaylarına yöneltilen "Türkçe derslerinizde küme çalışmalarına yer veriyor musunuz? Neden?" sorularına öğretmen adaylarının verdiği yanıtların dağılımı Tablo 5'te sunulmuştur:

Tablo 5. "Türkçe derslerinizde küme çalışmalarına yer veriyor musunuz? Neden?" sorusuna ilişkin öğretmen adaylarının görüşlerinin dağılımı

\begin{tabular}{llll}
\hline No & ifadeler & $\mathbf{f}$ & Ifadeler \\
\hline & & $\begin{array}{l}\text { "Keşfetme ve Derinleştirme aşamalarında grup çalışması etkinliğini kullandım. } \\
\text { Öğrencilerin birbirleriyle etkileşim sağlamaları, yardımlaşma ve fikir alışverişinde } \\
\text { bulunarak ortak karar almalarını sağlamak için grup çalışması yaptırdım." (K3) }\end{array}$ \\
1 & Evet & $\begin{array}{l}\text { "Konunun daha verimli olması ve özellikle sınıftaki öncelikle öğrencilerin birbiriyle } \\
\text { iletişimi çok kopuk olduğu için onların birbiriyle kaynaştırmayı sağlayabilmek } \\
\text { için." (K7) }\end{array}$ \\
& Hayır & $\begin{array}{l}\text { "Grup çalışmasını bir kere uyguladım ancak sınıf çok dağıldı ve sonra konuyu } \\
\text { toparlamakta zorlandım." (K2) }\end{array}$
\end{tabular}

Tablo 5'e göre öğretmen adaylarının yaklaşık yarısının Türkçe derslerinde grup çalışmalarına yer verdikleri görülmektedir. 
“Öğretmen Adayları Türkçe Derslerinde Öğrencilere Uygun Geribildirimler Vermekte Midir? Neler Söylemektedirler?” Sorusuna Illişkin Öğretmen Adaylarının Görüşlerinin Dağıımı

Araştırma kapsamında öğretmen adaylarına yöneltilen "Türkçe derslerinizde öğrencilere uygun geribildirimler veriyor musunuz? Neler söylüyorsunuz?" sorularına öğretmen adaylarının verdiği yanıtların dağılımı Tablo 6'da sunulmuştur:

Tablo 6. "Türkçe derslerinizde öğrencilere uygun geribildirimler veriyor musunuz? Neler söylüyorsunuz?" sorusuna ilişkin öğretmen adaylarının görüşlerinin dağııımı

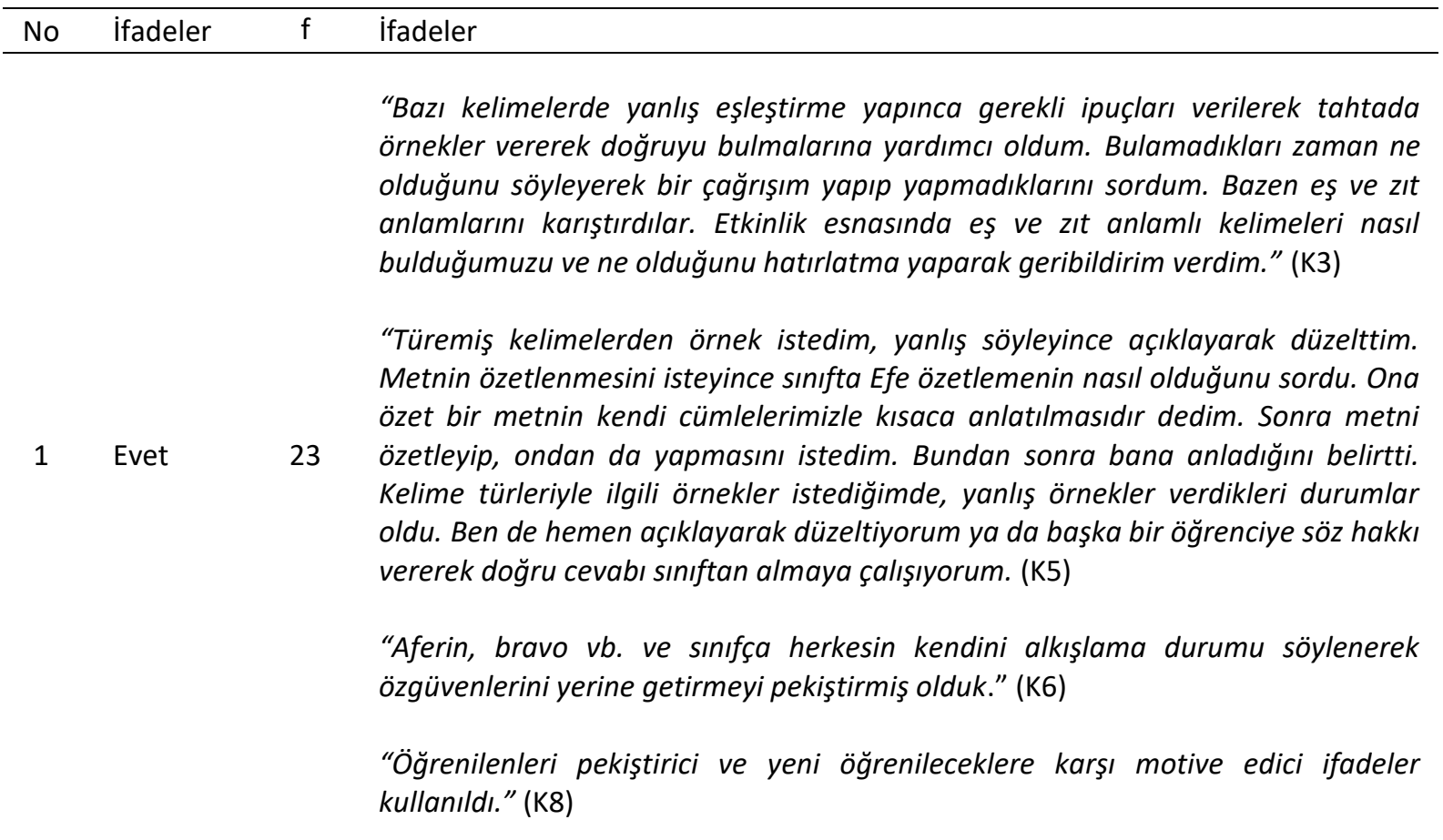

2 Hayır

Tablo 6'ya göre öğretmen adaylarının tamamına yakını Türkçe derslerinde uygun geribildirimler verdiklerini belirtmişlerdir. Öğretmen adaylarının geribildirim verirken, ipucu vermeye, hatırlatıcı ifadeler kullanmaya, açıklama yapmaya, sınıfça alkışlatmaya, motive edici ifadeler kullanmaya başvurdukları görülmektedir.

“Öğretmen Adaylarının Türkçe Derslerinde Sınıf Yönetimine iliş̧kin Görüşleri Nelerdir?” Sorusuna iliş̧kin Öğretmen Adaylarının Görüşlerinin Dağııımı

Araştırma kapsamında öğretmen adaylarına yöneltilen "Türkçe derslerinde sınıf yönetimi konusunda kendinizi nasıl değerlendiriyorsunuz? Neden?" sorularına öğretmen adaylarının verdiği yanıtların dağılımı Tablo 7'de sunulmuştur: 
Tablo 7. "Türkçe derslerinde sınıf yönetimi konusunda kendinizi nasıl değerlendiriyorsunuz? Neden?" sorusuna ilişkin öğretmen adaylarının görüşlerinin dağılımı

\begin{tabular}{|c|c|c|c|}
\hline No & ifadeler & $f$ & ifadeler \\
\hline & & & $\begin{array}{l}\text { "Konu için seçtiğim metin çok ilgilerini çekti. Yer yer konu dışına çıkmayacak } \\
\text { şekilde şakalar yaptık. Metin ile ilgili soruları cevaplarken özellikle "sizce"li } \\
\text { sorularda çok eğlendik. Bir öğrenci yanındakine bir şey sorduğunda bunu } \\
\text { görmezden geldim. Sınıf yönetimi olmazsa çocuklar derse yoğunlaşamaz, öğretim } \\
\text { gerçekleşmez." (K4) }\end{array}$ \\
\hline 1 & Yeterli & 18 & $\begin{array}{l}\text { "Sınıf yönetiminde etkili olduğumu düşündüm. Açıkçası bu derste bu kadar etkili } \\
\text { olacağımı düşünmüyordum. Sadece metin işlenecek, sorular sorulacak gibi } \\
\text { düşünüyordum. Derse başlamadan önce kısaca bu derste neler yapacağımdan } \\
\text { bahsettim. Çok iyi dinlediler, merakla derse başlamayı beklediler. Bu derste } \\
\text { gözden geçirmenin, güdülemenin, geçişlerin ve özetlerin önemini daha çok } \\
\text { anladım. Geçişlerde, gözden geçirmede kullandığım cümleleri dikkatlice } \\
\text { dinlediler. Buna çok sevindim. Soruları parmak kaldırıp söz aldıktan sonra } \\
\text { cevaplamalarını gerektiğini ilk başta defalarca söylemek zorunda kaldım. Daha } \\
\text { sonra istenilen şekilde söz almaya çalışanlara söz hakkı verdim ve onları }\end{array}$ \\
\hline 2 & $\begin{array}{l}\text { Kısmen } \\
\text { Yeterli }\end{array}$ & 3 & $\begin{array}{l}\text { "Sınıf içinde arkadaşları ve ders işlenirken uymaları gereken bazı kuralları derste } \\
\text { bağlantıları koptukça tekrarlamadım fakat pek başarılı olduğum konusunda emin } \\
\text { olamıyorum. Öğrencilerin bir ders saati diğerini tutmuyor bundan dolayı } \\
\text { zorlandığım anlar oldu. Ama ders anlatırken olabildiğince öğrencilerin hepsine } \\
\text { söz hakkı verdim." (K3) }\end{array}$ \\
\hline \multirow[b]{2}{*}{3} & \multirow[b]{2}{*}{ Yetersiz } & \multirow[b]{2}{*}{3} & $\begin{array}{l}\text { "Sınıf yönetiminde çok etkili olduğum söylenemez. Sınıf kalabalık olduğundan } \\
\text { öğrencilerin dikkatini toplamada zorluk çektim. Bir grubun dinlemesini sağlarken } \\
\text { diğerlerinin dikkati dağılıyor, konuşuyorlar. Daha çok soru sorduğumda onları } \\
\text { daha iyi kontrol edebiliyorum. Zaten dersi genelde soru-cevap şeklinde } \\
\text { işliyorum." (K9) }\end{array}$ \\
\hline & & & $\begin{array}{l}\text { "Sınıf yönetiminde sorunlar yaşadım. Öğrencilerin kendi öğretmenlerinin bile çok } \\
\text { zor sağladığı sınıf yönetimini sağlayamadım. Öğrenciler beni abileri olarak } \\
\text { gördükleri için (öğretmen yüzünden) beni önemsemediler. Öğretmenin gittiğini } \\
\text { gördüklerinde daha çok vahim oldu. Dersimin 3-4 kez bölünmesi de cabasıydı" } \\
\text { (K12) }\end{array}$ \\
\hline
\end{tabular}

Tablo 7 incelendiğinde, öğretmen adaylarının büyük çoğunluğu Türkçe derslerinde sınıf yönetimini sağlama konusunda kendilerinin yeterli olduğunu düşünmektedir. Katılımcılardan alınan görüşlere bağlı olarak öğretmen adaylarının, öğrencileri öğrenme-öğretme sürecine aktif katılmalarını sağlamada, istenmeyen davranışları gerekli durumlarda görmezden gelmede, derse ilgi çekici bir giriş yaparak öğrencilerin dikkatlerini çekmede, sınıf kuralları belirleme ve uygulamada ve pekiştireçler kullanmada kendilerini yeterli buldukları söylenebilir. Diğer taraftan öğretmen adayları; sınıf mevcudunun fazla olduğunda, kendi öğretmenlerinin de sınıf yönetimi sağlayamadığı sınıflarda, sınıf öğretmenlerinin öğretmen adaylarını "abi" olarak tanıtması nedeniyle öğrencilerin onları "abi” olarak gördüklerinde ve sınıf öğretmenleri sınıftan çıktığında sınıf yönetimini sağlamada yetersiz olduklarını ifade etmişlerdir. 
Öğretmen Adaylarının Türkçe Öğretimi Uygulamalarına ilişsin Görüşleri

"Öğretmen Adayları Türkçe Derslerinde Öğrencilerin Etkin Katılımını Sağlamak Için Neler Yapmaktadırlar?" Sorusuna Illişkin Öğretmen Adaylarının Görüşlerinin Dağılımı

Araştırma kapsamında öğretmen adaylarına yöneltilen "Türkçe derslerinizde öğrencilerin etkin katıımını sağlamak için neler yaptınız?" sorularına öğretmen adaylarının verdiği yanıtların dağılımı Tablo 8'de sunulmuştur:

Tablo 8. Öğretmen adaylarının öğrencileri etkin olarak derse katmak için yaptıkları etkinlikler

\begin{tabular}{clc}
\hline No & Yapılan Etkinlikler & $f$ \\
1 & Öğrencilerin sorulan soruları yanıtlaması & 21 \\
2 & Öğrencilerin metinleri sesli olarak okuması & 10 \\
3 & Öğrencilerin soru yazması & 4 \\
4 & Eğitsel oyunlar oynama & 4 \\
5 & Drama yapma & 4 \\
6 & Öğrencilerin okunan metinleri özetlemeleri & 3 \\
7 & Öğrencilere grup çalışması yaptırma & 2 \\
8 & Anlamı bilinmeyen sözcükleri sözlükten buldurma & 2 \\
9 & Öğrencilerin öykü oluşturmaları & 2 \\
10 & Belirlenen sözcükleri cümle içinde kullanma & 2 \\
11 & Öğrencilerin konuyla ilgili örnekler vermesi & 2 \\
12 & Öğrencilerin görselleri yorumlamaları & 1 \\
13 & Öğrencilerin soru sorması & 1 \\
14 & Okunan metni öğrencilere yorumlatma & 1 \\
\hline
\end{tabular}

Tablo 8'e göre öğretmen adayları Türkçe derslerinde öğrencilerin etkin katılımını sağlamak için çoğunlukla; öğrencilerin sorulan sorulara cevap vermelerini sağlamakta, öğrencilere metinleri sesli olarak okutmakta, öğrencilerin soru yazmalarını sağlamakta, eğitsel oyunlar oynatmakta ve drama yaptırmaktadırlar. Öğretmen adaylarının Türkçe derslerinde öğrencilerin etkin katılımlarını sağlamak için; öğrencilerin görselleri yorumlamaları, öğrencilerin soru sormalarını sağlama ve öğrencilerin okunan metni yorumlamalarına en az düzeyde yer verdikleri görülmektedir. En az düzeyde yer verilen etkinlikler arasında öğrencilerin yorum yapmalarına yönelik ifadelerin ise dikkat çekici olduğu söylenebilir.

"Öğretmen Adaylarının Deneyimlerine Bağlı Olarak Kendilerinde Başarılı Buldukları ve Geliştirmeleri Gereken Yönleri Nelerdir?” Sorusuna ilişskin Öğretmen Adaylarının Görüşlerinin Dağılımı

Araştırma kapsamında öğretmen adaylarına yöneltilen "Kendinizde başarılı olduğunuz ve geliştirmeniz gereken yönleriniz nelerdir?" sorularına öğretmen adaylarının verdiği yanıtların dağılımı Tablo 9'da sunulmuştur: 
Tablo 9. Öğretmen Adaylarının Kendilerinde Başarılıve Daha Az Başarılı Buldukları Özellikleri

\begin{tabular}{lll|ll}
\hline & Başarılı Bulunan Özellikler & $f$ & Geliştirilmesi Gereken Özellikler & $f$ \\
\hline 1 & Sınıfı yönetme ve öğrenciyi derse katabilme & & Sınıfı yönetme & 9 \\
& İletişim kurma ve öğrencilerin dikkatini & & Öğrenciyi etkin kılacak öğretim yöntemlerini & 5 \\
2 & çekme & 6 & seçme & 5 \\
3 & Soru-cevap yöntemini etkili kullanma & 4 & Öğrenci ilgisini canlı tutma & 3 \\
4 & Etkinlikleri yönlendirme & 4 & Konuyu günlük hayatla ilişkilendirme & 2 \\
5 & Vurgulu konuşma/diksiyon & 3 & Etkinlik hazırlama & 2 \\
6 & Adil olma & 2 & Materyal seçme & 2 \\
7 & Özgüvenli olma & 2 & Daha yavaş ve akıcı konuşma & 1 \\
8 & Öğrenciyi motive etme & 2 & Dilbilgisi öğretme & 1 \\
9 & Materyal kullanma & 2 & Ön hazırlık yapma & 1 \\
10 & Örnek olay bulma & 1 & Değerlendirme yapma & 1 \\
11 & İpuçları verme & 1 & Grup çalışması yaptırma & 1 \\
12 & Metnin anlaşılmasını sağlama & 1 & Öğrenciyi tanıma \\
13 & Yöntem bilgisine sahip olma & 1 & Zamanı etkili kullanma \\
14 & Yaratıcılık becerisine sahip olma & 1 & Öğrencinin derse katılımını sağlama & 1 \\
15 & Özetleme ve geçişlerde başarılı olma & 1 & Kalıcı öğrenmeyi sağlama & 1 \\
\hline
\end{tabular}

Tablo 9 incelendiğinde öğretmen adaylarının Türkçe derslerinde; sınıf yönetimi ve öğrenciyi derse katabilme, iletişim kurma ve öğrencilerin dikkatini çekme, soru-cevap yönetimini etkili kullanma ve etkinlikleri yönlendirme, vurgulu konuşma konularında kendilerini başarılı buldukları görülmektedir. Diğer yandan öğretmen adayları Türkçe derslerinde; sınıfı yönetme, öğrenciyi etkin kılacak yöntemleri seçme, öğrenci ilgisini canlı tutma, konuyu günlük hayatla ilişkilendirme konularında kendilerini geliştirmeleri gerektiğini düşünmektedirler. Öğretmen adaylarından sınıf yönetimi konusunda kendilerini başarılı bulanların sayısı ile sınıf yönetimi konusunda kendini geliştirmesi gerektiğini düşünen öğretmen adaylarının sayı olarak birbirine yakın olmasının oldukça dikkat çekici bulunduğu söylenebilir.

\section{Tartışma, Sonuç ve Öneriler}

$\mathrm{Bu}$ araştırmada öğretmen adaylarının Türkçe öğretimi kapsamında gerçekleştirdikleri uygulamalara ilişkin görüşlerinin belirlenmesi amaçlanmıştır. Araştırmada elde dilen verilere göre öğretmen adaylarının Türkçe derslerinde dikkat çekme ve güdüleme için en çok açık uçlu sorular sordukları, görsellerden yararlandıkları, konuyla ilgili kısa videolar izlettikleri, çocuk edebiyatından metinler okudukları belirlenmiştir. Öğretmen adaylarının Türkçe derslerinde en fazla; soru-cevap, anlatım, drama, 5E öğrenme döngüsü ve tartışma yöntem ve tekniklerini kullandıkları görülmüştür.

Öğretmen adayları Türkçe derslerinde sıklıkla yansıtıcı, bilgisayar, tahta, ders kitabı, Türkçe sözlük ve çalışma yapraklarını kullanmaktadırlar. Öğretmen adayları, Türkçe derslerinde metin seçerken en çok; öğrencilerin ön bilgileri, gelişim özellikleri, öğrencilerin düzeyi, ilgi çekiciliği, yazım ve 
içerik olarak uygun olması gibi özellikleri dikkate aldıklarını belirtmişlerdir. Öğretmen adayları Türkçe derslerinde en fazla öykü, ders kitabındaki metinler ve şiir kullanmaktadırlar. Öğretmen adaylarının yaklaşık yarısının Türkçe derslerinde küme çalışmalarına yer verdikleri belirlenmiştir.

Öğretmen adaylarının tamamına yakını Türkçe derslerinde uygun geribildirimler verdiklerini belirtmişlerdir. Öğretmen adaylarının geribildirim verirken, ipucu verme, hatırlatıcı ifadeler kullanma, açıklama yapma, sınıfça alkışlatma ve güdüleyici ifadeler kullanmaya başvurdukları görülmüştür. Öğretmen adaylarının büyük çoğunluğu Türkçe derslerinde sınıf yönetimini sağlama konusunda kendilerinin yeterli olduğunu düşünmektedir. Öğretmen adayları Türkçe derslerinde öğrencilerin etkin katılımını sağlamak için çoğunlukla; öğrencilerin sorulan sorulara cevap vermelerini sağlamakta, öğrencilere metinleri sesli olarak okutmakta, öğrencilerin soru yazmalarını sağlamakta, eğitsel oyunlar oynatmakta ve drama yaptırmaktadırlar.

Öğretmen adaylarının Türkçe derslerinde; sınıfı yönetme ve öğrenciyi derse katabilme, iletişim kurma ve öğrencilerin dikkatini çekme, soru-cevap yönetimini etkili kullanma ve etkinlikleri yönlendirme, vurgulu konuşma konularında kendilerini başarılı buldukları görülmüştür. Diğer yandan öğretmen adayları, Türkçe derslerinde; sınıfı yönetme, öğrenciyi etkin kılacak yöntemleri seçme, öğrenci ilgisini canlı tutma, konuyu günlük hayatla ilişkilendirme konularında kendilerini geliştirmeleri gerektiğini düşünmektedirler.

Bu araştırmada elde edilen bulgular diğer araştırma bulguları ile benzerlik göstermektedir. Örneğin, Aşkın (2011) tarafından gerçekleştirilen araştırmada da sınıf öğretmeni adaylarının kendilerini Türkçe öğretimi konusunda yeterli gördükleri sonucuna ulaşılmıştır. Yılmaz (2010) araştırmasında, Türkçe öğretmeni adaylarının, Türkçe öğretimi özel alan yeterliklerini gerçekleştirme düzeylerinin ve Türkçe öğretimi öz yeterliklerinin "yeterli" olduğu sonucuna ulaşmıştır. Özdemir ve Erdoğan'ın (2017) çalışmasında da sınıf öğretmeni adaylarının Türkçe derslerinde özellikle ilk okuma yazma öğretimi konusunda öz güvenlerinin yüksek olduğu, kız öğrencilerin erkek öğrencilere oranla öz yeterlik puanlarının daha yüksek olduğu vurgulanmıştır. Benzer şekilde Değirmenci Gündoğmuş'un (2018) çalışmasında sınıf öğretmeni adayları ilkokuma yazma öğretimi konusunda iyi olduklarını düşündüklerini ifade etmişlerdir. Sözü geçen çalışmada kız öğretmen adaylarının erkek öğretmen adaylarına kıyasla daha yüksek öz yeterlik düzeyine sahip oldukları belirlenmiştir.

Bu çalışma aynı zamanda, Yavuz (2009)'un, öğretmen adaylarının öğretmenlik mesleğine ilişkin yaptığı çalışma ile benzer sonuçlara sahiptir. Yavuz'un araştırmasına göre, öğretmen adayları kendilerini öğretmenlik mesleği konusunda "yeterli" görmektedirler. Drummond ve Stoddard (1990), öğretmen adaylarının, öğrencilerin eğitimleri için ne gibi yeterliklere sahip olmaları gerektiğini araştırmışlardır. Öğretmenlere, öğretmen adaylarının sahip olması gereken yeterlikler sorulmuştur. Araştırmaya göre, öğretmen adaylarının öncelikli olarak iletişim becerilerine, ikinci olarak alan bilgisi 
yeterliğine sahip olmaları gerektiği sonucuna ulaşılmıştır. Ayrıca Çakmak (2010) ve Ak'ın (2006) yaptıkları araştırmalarda sınıf öğretmenlerinin Türkçe dersinde farklı yöntem ve teknikleri kullandıkları belirlenmiştir. Buradaki bulgular, bu araştırmada elde edilen bulguları destekler niteliktedir.

Gökçe (1999), ilköğretim öğretmenlerinin sahip olması gereken yeterliklere ne düzeyde sahip olduklarını incelediği araştırması sonucunda ilköğretim öğretmenlerinin; çocuk gelişimi, sınıf içi iletişim, öğretim yöntemleri, okuma öğretimi, yazma öğretimi, matematik öğretimi, sınıf yönetimi, öğrenci başarısını değerlendirme, okul-aile işbirliği ve mesleki-kişisel alandaki yeterliklere yeterince sahip oldukları ortaya çıkmıştır. Buna karşılık, öğretmenlerin program geliştirme ve değerlendirme alanındaki yeterliklere oldukça düşük düzeyde sahip oldukları sonucuna ulaşılmıştır. Susar Kırmızı ve Akkaya (2009) tarafından gerçekleştirilen araştırma sonuçlarına göre öğretmenlerin; etkinliklere, materyal kullanımına, Türkçe Öğretiminin beceri alanlarına ve hizmet içi eğitime yönelik olarak sorunlar yaşadıkları sonucuna ulaşılmıştır. Her iki araştırmadaki bulguların bazılarının, bu araştırmada elde dilen bulgular ile örtüştüğü söylenebilir.

Sonuçları bu araştırmanın bulgularından farklı olan bazı çalışmalar da vardır. Karaca (2004) tarafından öğretmen adaylarının ölçme ve değerlendirme yeterliklerine ilişkin algıları ile ilgili yaptığı çalışmada, öğretmen adaylarının kendilerini ölçme değerlendirme konusunda yeterli görmedikleri ortaya koyulmuştur. Yine bir diğer araştırmada Anılan ve Kılıç (2013), sınıf öğretmeni adaylarının fakültedeki Türkçe Öğretimi dersini işlevsel buldukları, Türkçe Öğretimi yaparken dil bilgisi konularının öğretiminde zorlanabilecekleri sonucuna ulaşmışlardır.

Araştırmada elde edilen sonuçlar doğrultusunda farklı araştırmalarda; öğretmen adayları farklı öğretim yöntem ve tekniklerini kullanarak Türkçe ders planları hazırlamaya yönlendirilebilir, öğretmen adaylarının Türkçe derslerinde kendilerini geliştirmeleri gerektiğini düşündükleri konularda neler yapabileceklerine ilişkin çalışmalar yapılabilir. Diğer yandan öğretmen adayları tarafından sunulan Türkçe derslerine ilişkin mikro öğretim uygulamaları gerçekleştirilerek Türkçe derslerinin niteliğinin artırımasına katkı sağlanabilir. Özdemir ve Erdoğan'ın (2017) çalışmasında sınıf öğretmeni adayları alanda uygulama yaptıkça öz yeterliklerinin arttığına vurgu yapmıştır. Dolayısıyla, öğretmen adaylarının üniversite eğitimleri boyunca gerçekleştirdikleri teorik öğrenmelerini alanda uygulayabilmelerine yönelik çalışmalara yer verilmesi ve üniversite ve okul işbirliklerinin arttırılması önerilebilir. 


\section{Kaynaklar}

Adalı, O. (1983). Anadili olarak Türkçe öğretimi üstüne. Dil Öğretimi Özel Sayı Türk Dili ve Edebiyatı Dergisi, 47 (379), 31-35.

Ak, F. Ö. (2006). İlköğretim okulları 1-5. sınıflarda uygulanmaya başlayan yeni ilköğretim programı hakkında sınıf öğretmenlerinin görüşlerinin incelenmesi. Yayımlanmamış yüksek lisans tezi, Yeditepe Üniversitesi Sosyal Bilimler Enstitüsü, İstanbul.

Akyol, H. (2010). Türkçe öğretim yöntemleri (Yeni programa uygun). Ankara: Pegem Akademi.

Anılan, H. ve Kılıç, Z. (2013). Sınıf öğretmeni adaylarının Türkçe öğretimi dersine ve Türkçe öğretimi konusundaki yeterliliklerine ilişkin görüşleri. Adıyaman Üniversitesi Sosyal Bilimler Enstitüsü Dergisi. 13, $1-48$.

Aşkın. İ. (2011). Sınıf öğretmeni adaylarının Türkçe öğretimi yeterliliklerine ilişkin görüşleri. Yayınlanmış Yüksek Lisans Tezi, Hacettepe Üniversitesi Sosyal Bilimler Enstitüsü.

Bogdan, C. R. ve Biklen, K. S. (2007). Qualitative research for education an introduction to theories and methods. USA: Person International Edition.

Boyacı, Z. Ve Kılıç, A. (2017). Bireylerin geleceğinin şekillenmesine sınıf öğretmenlerinin etkisi (Primary school teachers' effects on forming the future of individuals). Kastamonu Eğitim Dergisi, 25 (2), 701-718.

Çakmak, G. (2010). İlköğretim birinci kademe Türkçe öğretim programının öğrencilerin yaratıcı düşünmelerini geliştirmeye etkisine yönelik öğretmen görüşleri. Yayımlanmamış yüksek lisans tezi, Fırat Üniversitesi Sosyal Bilimler Enstitüsü, Elazı̆̆.

Değirmenci Gündoğmuş, H. (2018). Self-efficacy of teacher candidates for teaching first reading and writing.

Educational Research and Reviews, 13(6), 224-229.

Drummond, R. ve Stoddard, A. (1990). Teacher competencies: What is the role of foundations of education? Journal of Instructional Psychology, 17(2), 65-67.

Erdem, İ. ve Çelik, M. (2011). Dil bilgisi öğretim yöntemi üzerine değerlendirmeler. Turkish Studies, 6(1), 10301041.

Evran Acar, F. (2010). Sınıf öğretmenliği programından mezun olan öğretmenlerin Türkçe dersine ilişkin yeterliklerinin değerlendirilmesi. Türk Eğitim Bilimleri Dergisi, 8(1), 89-115.

Gökçe, E. (1999). Ilköğretim öğretmenlerinin yeterlikleri. Yayımlanmamış Doktora Tezi. Ankara: Ankara Üniversitesi, Sosyal Bilimler Enstitüsü.

Karaca, E. (2004). Öğretmen adaylarının ölçme ve değerlendirme yeterliklerine ilişkin algıları. Yayımlanmamış Doktora Tezi. Eskişehir: Anadolu Üniversitesi, Sosyal Bilimler Enstitüsü.

Kavcar, C. (1988). Türk dili ve edebiyatı öğretimi. Ankara Üniversitesi Eğitim Bilimleri Fakültesi Dergisi, 20(1-2), 261-273.

Kavcar, C., Oğuzkan, F. ve Sever, S. (2005). Türkçe öğretimi (Türkçe ve sınıf öğretmenleri için). Ankara: Engin Yayınları.

Özdemir, C., ve Erdoğan, T. (2017). Sınıf öğretmeni adaylarının ilkokuma ve yazma öğretimine ilişkin öz yeterlik inançlarının belirlenmesi. Abant İzzet Baysal Üniversitesi Eğitim Fakültesi Dergisi, 17 (1), 314-331.

Senemoğlu, N. (1992). İngiltere'de ilköğretime öğretmen yetiştirme ve Türkiye ile karşılaştırılması-Türkiye'de ilköğretime öğretmen yetiştirmenin geliştirilmesi için bazı öneriler. Hacettepe Üniversitesi Eğitim Fakültesi Dergisi, 8, 143-156.

Sever, S. (2003). Türkçe öğretimi ve tam öğrenme. Ankara: Anı yayıncılık.

Susar Kırmızı, F. ve Akkaya, N. (2009). Türkçe öğretimi programında yaşanan sorunlara ilişkin öğretmen görüşleri. Pamukkale Üniversitesi Eğitim Fakültesi Dergisi, 25, 42-54. 
Yavuz, D. (2009). Öğretmen adaylarının öğretmenlik mesleğine yönelik öz yeterlik algıları ve üst bilişsel farkındalıklarının çeşitli değişkenler açısından incelenmesi. Yayımlanmamış Yüksek Lisans Tezi. Zonguldak: Zonguldak Karaelmas Üniversitesi, Sosyal Bilimler Enstitüsü.

Yıldııım, A. ve Şimşek, H. (2011). Sosyal bilimlerde araştırma yöntemleri. Ankara: Seçkin Yayınları.

Yılmaz, İ. (2010). Türkçe öğretmeni adaylarının özel alan ve öz yeterlik algıları. Yayımlanmamış Yüksek Lisans Tezi. Erzurum: Atatürk Üniversitesi, Sosyal Bilimler Enstitüsü.

\section{Extended Abstract Introduction}

In most cases, elementary school students begin their education with a prior working knowledge of their mother tongue. In normal childhood development, children begin acquiring use of their native language at an early age through experiences and interactions with their parents, other caregivers, peers, and so forth. Even though natural language acquisition occurs from an infant and young child's interaction with their family and others around them, this language development is insufficient in terms of the rules and proper use of the language necessary for a student to succeed in their formal education. Some students may have difficulty in being successful in some academic disciplines because of a lack of the required language skills developed through primary education. In the Republic of Turkey, it is important that students are successful and welleducated, and as a result, according to the general objectives and principles of Turkish National Education system gaining enough knowledge, skills, and usage of their native language is a priority. The responsibility of adequately educating and preparing elementary school students for use of their mother tongue in academic settings rests on the elementary school teacher; particularly on the classroom teacher being able, qualified, and ready to provide instruction regarding appropriate native language use to their students.

The primary goals for teaching language to young individuals are to improve their cognitive abilities and communication skills, increase their comprehension levels, contribute to their socialization process, habituate them to positive reading and listening skills, develop and enrich their vocabulary, teach them basic rules of grammar, create language awareness and a passion for language (Kavcar, 1988; Kavcar, Oğuzkan \& Sever, 2005).

In Turkey, language learning occurs indirectly from the variety of instruction which takes place in all courses. However, the primary responsibility for teaching the Turkish language to students is managed by Turkish language courses. As a result, Turkish language course instruction has the important responsibility of increasing individuals' linguistic skills and language habits based on their mental and social needs (Kavcar et al., 2005).

Providing effective and qualified instruction of the Turkish language in elementary schools has a direct correlation with the expertise, knowledge, skill and overall qualifications of the classroom teachers. In Turkish elementary school classrooms, the classroom teacher has the most active role in the teaching-learning process because student and teacher interactions are in effect constant. The teacher is responsible for not only day-today classroom instruction but also the implementation of specific training programs and the management of evaluation (Evran-Acar, 2010). As a result, classroom teachers are expected to have acquired and developed the required knowledge and skills for teaching language. During their undergraduate studies, in particular; as part of a Turkish language education course, teacher candidates gain the necessary knowledge and skills to prepare them for Turkish language instruction in the elementary school classroom. For this reason, determining teacher candidates' views regarding the classroom practices performed as part of Turkish language instruction is considered an important contribution for enhancing teacher qualifications related to language teaching. Therefore, the purpose of this study is to investigate pre-service teachers' opinions regarding the application of the knowledge and skills they acquired through their undergraduate teacher education program to Turkish language instruction in the elementary classroom.

Method

The participants of the study were 26 pre-service teachers enrolled in Ankara University, Department of Elementary Education during the 2015-2016 spring semester, and enrolled in a Teaching Turkish Language in Elementary School Classrooms course. Data were collected from 26 pre-service teachers' responses to openended questions from a prepared Opinion Form. The collected data were analysed and interpreted through descriptive analysis techniques.

\section{Result and Discussion}

The findings revealed that in order to get students' attention and motivate them, the pre-service teachers utilized a variety of teaching strategies, for example; asking open-ended questions, using visuals and short videos, and reading children's literature in the classroom. In addition, the pre-service teachers stated that 


\section{Öğretmen Adaylarının Türkçe Öğretimi Uygulamalarına İlişkin Görüşleri}

projection equipment, computers, black/white board, textbooks, Turkish language dictionaries, and worksheet were the mostly utilized materials in the classroom for language instruction.

Furthermore, the pre-service teachers' responses regarding the teaching methods they utilized the most were; question and answer, lecture, drama, the 5E learning cycle and class discussion. Finally, when teaching Turkish language courses, the study responses revealed that pre-service teachers utilized stories, texts from textbooks, and poems, the most.

Other important information provided by pre-service teacher responses were that when determining which texts to be utilized in the classroom they considered their students' prior knowledge and developmental characteristics and questioned whether the texts were appropriate and interesting. Approximately half of the participants responded that while teaching the Turkish language course they allowed their students to work with peers and complete group activities. In addition, almost all participants stated that they believed they provided appropriate feedback to their students.

The pre-service teachers also stated that in order to ensure active course participation from students, they utilized a variety of methods such as encouraging students to respond to questions, allowing students to read texts aloud, asking students to formulate and write their own questions, playing educational games, and using drama.

Furthermore, in order to ensure students' active participation to classroom activities, pre-service teachers stated that they used specific teaching strategies including; asking students to interpret visuals, encouraging students to ask questions, and asking students to interpret the texts they read with a few sentences. Even though the students were only allowed limited opportunities such as commenting on classroom activities and paraphrasing the texts they read, these strategies still proved to be of valuable classroom resource.

Finally, the pre-service teachers responded that they believed they were successful at managing their classrooms, allowed students to participate in the lesson, provided effective communication, maintained the students' attention, used the question and answer technique, organized activities well, and used the appropriate level of intonation when teaching. However, the pre-service teachers also responded that they needed continuous professional development in some areas such as organizing the classroom, locating and utilizing effective teaching methodologies, keeping students' interest alive and activity level high, as well as, connecting students' in school learning with their real life experiences. 